\title{
Insect Diversity of the Muni-Pomadze Ramsar Site: An Important Site for Biodiversity Conservation in Ghana
}

\author{
Rosina Kyerematen, ${ }^{1,2}$ Daniel Acquah-Lamptey, ${ }^{1}$ Erasmus Henaku Owusu, \\ Roger Sigismund Anderson, ${ }^{2}$ and Yaa Ntiamoa-Baidu ${ }^{1,3}$ \\ ${ }^{1}$ Department of Animal Biology and Conservation Science, P.O. Box LG67, University of Ghana, Legon, Ghana \\ ${ }^{2}$ African Regional Postgraduate Programme in Insect Science, P.O. Box LG59, University of Ghana, Legon, Ghana \\ ${ }^{3}$ Centre for African Wetlands, University of Ghana, Legon, Ghana \\ Correspondence should be addressed to Rosina Kyerematen; rkyerematen@ug.edu.gh
}

Received 5 September 2013; Revised 16 December 2013; Accepted 5 January 2014; Published 20 February 2014

Academic Editor: Victoria Soroker

Copyright (c) 2014 Rosina Kyerematen et al. This is an open access article distributed under the Creative Commons Attribution License, which permits unrestricted use, distribution, and reproduction in any medium, provided the original work is properly cited.

\begin{abstract}
An inventory of species diversity of insects of the Muni-Pomadze Ramsar site, with special reference to species of conservation concern, was carried out as part of an evaluation of changes in the ecological character of the site, twenty years after designation. Samples were taken from two protected areas within the Ramsar site, in the wet (July), dry (January), and intermediate (June) seasons. Community diversity was characterized in terms of number of species accumulated, species richness, Shannon-Weiner indices of diversity, Pielou's evenness, and Bray-Curtis similarity. A total of 134 families from 19 insect orders were recorded during the entire study period. Yenku Block A recorded the highest species richness (98) and the highest diversity index (14.97), corroborated by the highest Margalef index of 3.82 with a relatively even distribution of species (0.834) during the intermediate season, and recorded the lowest diversity (6.957) and species richness (41) during the dry season. On the whole, the Muni-Pomadzi Ramsar site showed a high diversity of insect species. The presence of species such as Junonia oenone and Papilio demodocus which are specialized in degraded habitats at Yenku Block A in large numbers is a clear indication of degradation of the forest, but the presence of forest species such as Salamis anacardii and Euphaedra crokeri is an indication that some parts of this reserve are still in good shape. A comparison of the butterfly species recorded with findings in a 1997 survey showed a marked increase in numbers from 75 to 130; this may be attributed to the habitat changes that have taken place at the site offering more diverse habitat types.
\end{abstract}

\section{Introduction}

Insects constitute a remarkably speciose group of organisms attributed mainly to their small size, which allows them to occupy niches not available to larger organisms. They are adapted to highly differing environments from the Arctic tundra to Alpine mountain summits as well as warmer tropical rainforest and coastal mangrove swamps and are able to tolerate extremes of temperature and other environmental conditions. Estimates of global species richness of insects vary from less than five million to as many as 80 million [1].

Insects are critical natural resources in ecosystems, particularly those of forests [2]. In addition to their role as efficient pollinators and natural/biological pest control agents, some insect species are important indicators in ecosystems management [3]. The habitat heterogeneity hypothesis simply predicts that more arthropod species will occur where different forms and species of plants provide greater structural heterogeneity in the vegetation [4]. Thus, greater resources are available for the coexistence of more species within each trophic group [5]. Arthropod diversity, which takes account of the relative abundance of species as well as their variety [6], would express an asymptotic relationship with increasing numbers of plant species and greater structural heterogeneity in the vegetation. Habitat heterogeneity at small spatial scales can favour the number and abundance of arthropod species in grassland [7], for example.

Insects are essential in the ecosystem by helping in nutrient recycling through leaf litter and wood degradation, carrion and dung disposal, and soil turnover. They play a 
major role in plant pollination and maintenance of plant community composition and structure via phytophagy [1]. Their demise will therefore result in the disruption of critical ecosystem services such as pollination and source of food. There is therefore the need for the conservation and protection of these species. Indeed the forest canopy is the heart of biotic diversity and thus it is imperative that the forest be properly managed to ensure the persistence of such a unique group of nature, which is critical for ecosystem health.

The Muni-Pomadze Ramsar site was designated in 1992. A few years after its designation, an assessment of the insect diversity of the site and its surroundings in relation to habitat characteristics was carried out by the Coastal Wetlands Management Project (CWMP) funded by the Global Environment Facility (GEF) [8]. This study was carried out to (i) present more detailed descriptive baseline data from an intensive entomological survey in an important site for conservation in West Africa, (ii) provide an inventory of the insect diversity and abundance with special reference to species of conservation concern, and (iii) assess the changes that have taken place in the ecological character of the Ramsar site.

\section{Materials and Methods}

2.1. Sampling Sites. The Muni-Pomadze Ramsar site is situated to the west of the coastal town of Winneba in the Central Region of Ghana, approximately $55 \mathrm{~km}$ from Accra and encompasses approximately $90 \mathrm{~km}^{2}$ of the watershed surrounding the Muni Lagoon as well as two protected areas: Yenku Block A and Yenku Block B $[2,9]$. At the time of the current study, Yenku Block A, north of the village of Onyadze, was a degraded natural forest interspersed with pockets of farmlands and Teak, Eucalyptus, and Acacia plantations with a few thickets of dense shrubs. Yenku Block B which is close to Mankoadze near the coast consisted mainly of open savanna grassland interspersed with thickets and small trees. An Eucalyptus plantation bordered this area to the north at the foot of the Egyasimanku Hills with maize farms to the south.

2.2. Methods. The field studies were carried out in July 2011, January, and June 2012, the wet, dry, and intermediate seasons, respectively. Eight main sampling methods were employed in the collection of insects. Butterfly nets were used for butterflies, dragonflies, and other high flying insects; visual observations and counts were done for those insects that were missed by the nets and also for insects species of which individuals had already been captured since it was not necessary to capture more insects than necessary. At each site, one Malaise trap for smaller, flying, mainly nocturnal insects, one flight interception trap (FIT) designed to intercept insects in flight and five Charaxes traps for alcohol-loving butterflies and other insects that are attracted to fermenting foods were set up. Rotten banana, mashed and mixed with alcohol (palm wine and or beer), was used as bait for the Charaxes traps. In addition, pitfall and yellow pan traps (five of each) were randomly set up at each site for crawling and ground dwelling insects and insects attracted by the yellow colour; sweeping was done for vegetation-dwelling insects and handpicking with forceps was done for insects within easy reach. Light trapping which lasted about two hours was done for the nocturnal insects along a small stream at Yenku Block B.

In addition to the various trapping methods, random walk sampling was undertaken by three persons for a minimum of three hours during each sampling period twice each day for seven days at each site. Visual observations and counts were done mainly for the dragonflies since they are very fast fliers and difficult to catch.

Insects collected were killed using a killing bottle containing ethyl acetate and kept either in alcohol or glassine envelops for later examination and identification. Identification of insects was done with reference to the collection in the Museum of the Department of Animal Biology and Conservation Science, University of Ghana, as well as with reference to Carter [10], Gullan and Cranston [1, 11], Scholtz and Holm [12], Chinery [13, 14], Carcasson [15], Crowson [16], Belcastro and Larsen [17], Larsen [18], Miller [19], McGavin [20], Pinheiro and Ortiz [21], and Dijkstra and Clausnitzer [9].

\section{Data Analyses}

Cluster analysis was performed using Bray-Curtis similarity. Species contributing at least 20 individuals of the total abundance at each sampling site were included in the analysis. The original data was transformed (fourth root transformation) and standardized in order to minimize the weighting of numerically dominant species.

Five diversity indices were computed [22].

(1) Total Species. S-the number of species in each sample, that is, species with nonzero counts.

(2) Total Individuals. $N$-the number of individuals in each sample.

(3) Species Richness (Margalef).d $=(S-1) / \log (N)$-This is a measure of the number of species present, making some allowance for the number of individuals.

(4) Pielou's Evenness. This is a measure of equitability, a measure of how evenly the individuals are distributed among the different species.

(5) Shannon-Wiener Index. It incorporates both species richness and equitability components.

\section{Results}

A total of 8634 individual insects belonging to 134 families and 19 orders were recorded in the survey. We present the butterflies and dragonflies data separately because of their numerical abundance, conservation interest, and role as indicators of ecosystem health but group all the other insects.

4.1. Butterflies. 130 species of butterflies (Table 1) belonging to nine families were recorded during the survey: Nymphalidae, Papilionidae, Hesperiidae, Pieridae, Satyridae, Danaidae, Charaxidae, Acraedae, and Lycaenidae, with the Pieridae dominating with 39 species, followed by Nymphalidae with 37 species. 
TABLE 1: Butterfly species recorded over the entire survey period.

\begin{tabular}{|c|c|c|c|c|c|c|}
\hline \multirow{2}{*}{ Species } & \multicolumn{3}{|c|}{ Yenku Block A } & \multicolumn{3}{|c|}{ Yenku Block B } \\
\hline & July & January & June & July & January & June \\
\hline Euryphene barombyna & 2 & 2 & 1 & 0 & 0 & 1 \\
\hline Euryphene sp. & 1 & 1 & 0 & 0 & 0 & 0 \\
\hline Euphaedra sarcoptera & 12 & 2 & 4 & 0 & 0 & 0 \\
\hline Euphaedra edwardsi & 2 & 1 & 0 & 0 & 0 & 0 \\
\hline Euphedra hapalyce & 5 & 1 & 2 & 0 & 0 & 0 \\
\hline Euphaedra eleus & 2 & 1 & 0 & 0 & 0 & 0 \\
\hline Euphaedra medon & 9 & 2 & 3 & 0 & 0 & 0 \\
\hline Euphaedra crockeri & 4 & 1 & 2 & 0 & 0 & 0 \\
\hline Euphaedra xypete & 14 & 1 & 4 & 0 & 0 & 0 \\
\hline Euphaedra sp. & 3 & 0 & 2 & 0 & 0 & 0 \\
\hline Eurytela dryope & 12 & 3 & 23 & 0 & 0 & 0 \\
\hline Pseudoacrea sp. & 9 & 2 & 4 & 55 & 0 & 1 \\
\hline Pseudoneptis ianthe & 3 & 0 & 2 & 0 & 0 & 0 \\
\hline Pseudoneptis sp. & 1 & 0 & 1 & 0 & 0 & 0 \\
\hline Diestogina feronia & 2 & 1 & 1 & 0 & 0 & 0 \\
\hline Neptis melicerta & 3 & 6 & 3 & 3 & 0 & 14 \\
\hline Neptis agatha & 1 & 3 & 5 & 10 & 0 & 4 \\
\hline Neptis metella & 2 & 2 & 9 & 2 & 0 & 3 \\
\hline Neptis merosa & 1 & 1 & 3 & 1 & 0 & 0 \\
\hline Neptis seeldrayersi & 0 & 0 & 2 & 0 & 0 & 0 \\
\hline Salamis anacardii & 3 & 1 & 1 & 0 & 0 & 0 \\
\hline Junonia terea & 43 & 3 & 27 & 2 & 0 & 6 \\
\hline Junonia oenone & 1 & 1 & 2 & 6 & 5 & 60 \\
\hline Junonia octavia & 0 & 11 & 2 & 0 & 0 & 10 \\
\hline Junonia sp. & 2 & 1 & 2 & 1 & 1 & 0 \\
\hline Gnophodes chelys & 3 & 3 & 5 & 0 & 0 & 0 \\
\hline Gnophodes betsimena & 0 & 2 & 1 & 0 & 0 & 0 \\
\hline Kallima rumia & 2 & 1 & 3 & 0 & 0 & 0 \\
\hline Phalanta phalanta & 13 & 6 & 29 & 75 & 3 & 66 \\
\hline Ariadne enotera & 8 & 1 & 14 & 0 & 0 & 1 \\
\hline Aterica galene & 2 & 1 & 1 & 0 & 0 & 0 \\
\hline Aterica sp. & 7 & 0 & 1 & 0 & 0 & 0 \\
\hline Byblia achelola & 2 & 4 & 2 & 0 & 0 & 0 \\
\hline Byblia sp. & 1 & 1 & 3 & 0 & 0 & 0 \\
\hline Hypolimnas salmacis & 2 & 2 & 1 & 0 & 1 & 0 \\
\hline Hypolimnas missipus & 1 & 1 & 2 & 0 & 0 & 0 \\
\hline Hypolimnas dinarcha & 1 & 2 & 0 & 0 & 0 & 0 \\
\hline Acraea epaea & 2 & 3 & 5 & 7 & 6 & 13 \\
\hline Acraea zetes & 4 & 5 & 8 & 37 & 13 & 65 \\
\hline Acraea terpsichore & 0 & 4 & 7 & 0 & 0 & 24 \\
\hline Acraea pseudolycia & 0 & 0 & 1 & 0 & 0 & 0 \\
\hline Acraea doubledayi & 0 & 0 & 2 & 0 & 0 & 0 \\
\hline Acraea egina & 1 & 0 & 3 & 0 & 0 & 0 \\
\hline Acraea sp. & 1 & 2 & 4 & 16 & 4 & 11 \\
\hline Bematistis epaea & 4 & 5 & 6 & 0 & 2 & 14 \\
\hline Hallelesis haliwa & 2 & 1 & 0 & 1 & 0 & 0 \\
\hline Hallelesis sp. & 4 & 1 & 1 & 0 & 0 & 0 \\
\hline Ypthima itonia & 0 & 1 & 3 & 0 & 0 & 0 \\
\hline
\end{tabular}

TABle 1: Continued.

\begin{tabular}{|c|c|c|c|c|c|c|}
\hline \multirow{2}{*}{ Species } & \multicolumn{3}{|c|}{ Yenku Block A } & \multicolumn{3}{|c|}{ Yenku Block B } \\
\hline & July & January & June & July & January & June \\
\hline Bicyclus zinebi & 11 & 3 & 3 & 1 & 0 & 0 \\
\hline Bicyclus safitza & 13 & 2 & 5 & 2 & 0 & 3 \\
\hline Bicyclus auricruda & 0 & 1 & 3 & 0 & 0 & 0 \\
\hline Mycalensis safitza & 1 & 1 & 5 & 0 & 0 & 1 \\
\hline Mycalensis sp. & 5 & 0 & 1 & 6 & 0 & 0 \\
\hline Bicyclus vansoni & 0 & 2 & 0 & 0 & 0 & 0 \\
\hline Bicyclus condamini & 0 & 1 & 1 & 0 & 0 & 0 \\
\hline Bicyclus vulgaris & 0 & 1 & 0 & 0 & 0 & 0 \\
\hline Papilio demodocus & 18 & 8 & 21 & 112 & 11 & 66 \\
\hline Papilio dardaunus & 3 & 5 & 2 & 0 & 1 & 0 \\
\hline Papilio nireus & 23 & 4 & 29 & 0 & 0 & 0 \\
\hline Papilio bromius & 3 & 1 & 2 & 0 & 0 & 0 \\
\hline Graphium policenes & 2 & 4 & 3 & 1 & 0 & 1 \\
\hline Papilio menesthius & 1 & 2 & 1 & 0 & 0 & 2 \\
\hline Amauris niavus & 3 & 2 & 5 & 1 & 0 & 0 \\
\hline Amauris egialea & 2 & 1 & 3 & 1 & 0 & 0 \\
\hline Amauris sp. & 1 & 1 & 2 & 1 & 0 & 0 \\
\hline Danaus chryssipus & 2 & 125 & 8 & 13 & 24 & 7 \\
\hline Danaus limniace & 0 & 1 & 2 & 0 & 0 & 0 \\
\hline Eurema brigitta & 17 & 8 & 9 & 206 & 5 & 40 \\
\hline Eurema senegalensis & 9 & 2 & 3 & 16 & 2 & 11 \\
\hline Eurema hecabe & 6 & 13 & 8 & 3 & 1 & 11 \\
\hline Eurema lisa & 11 & 3 & 4 & 7 & 1 & 0 \\
\hline Eurema brenda & 0 & 0 & 1 & 0 & 0 & 0 \\
\hline Eurema sp. & 13 & 2 & 5 & 4 & 0 & 0 \\
\hline Colias philodice & 4 & 2 & 1 & 0 & 0 & 0 \\
\hline Pieris rapae & 3 & 4 & 6 & 0 & 2 & 26 \\
\hline Pieris sp. & 4 & 2 & 3 & 1 & 1 & 10 \\
\hline Nepheronia thalassina & 18 & 15 & 21 & 2 & 3 & 29 \\
\hline Nepheronia argia & 22 & 8 & 18 & 0 & 3 & 35 \\
\hline Nepheronia sp. & 5 & 3 & 6 & 0 & 0 & 0 \\
\hline Leptosia alcesta & 21 & 8 & 33 & 0 & 0 & 0 \\
\hline Leptosia medusa & 18 & 10 & 22 & 0 & 0 & 0 \\
\hline Leptosia sp. & 8 & 3 & 5 & 0 & 0 & 0 \\
\hline Appias phaola & 0 & 1 & 3 & 0 & 0 & 0 \\
\hline Dixeia astarte & 1 & 0 & 8 & 3 & 1 & 0 \\
\hline Dixeia cebon & 8 & 3 & 23 & 4 & 2 & 3 \\
\hline Colotis erone & 9 & 4 & 22 & 7 & 25 & 13 \\
\hline Colotis danae & 7 & 2 & 3 & 5 & 8 & 3 \\
\hline Colotis evippe & 12 & 8 & 14 & 11 & 5 & 7 \\
\hline Colotis antevippe & 18 & 2 & 24 & 20 & 3 & 85 \\
\hline Colotis evinina & 6 & 3 & 9 & 9 & 3 & 62 \\
\hline Colotis eunoma & 4 & 0 & 5 & 3 & 2 & 5 \\
\hline Anthocharis cardamine & 4 & 4 & 6 & 3 & 0 & 3 \\
\hline Belinois calypso & 68 & 15 & 87 & 12 & 8 & 66 \\
\hline Belinois creona & 32 & 5 & 46 & 9 & 1 & 20 \\
\hline Belinois theora & 16 & 1 & 19 & 12 & 0 & 14 \\
\hline Belinois gidica & 18 & 4 & 7 & 14 & 0 & 2 \\
\hline
\end{tabular}


TABLE 1: Continued.

\begin{tabular}{|c|c|c|c|c|c|c|}
\hline \multirow{2}{*}{ Species } & \multicolumn{3}{|c|}{ Yenku Block A } & \multicolumn{3}{|c|}{ Yenku Block B } \\
\hline & July & January & June & July & January & June \\
\hline Belinois aurota & 14 & 3 & 12 & 21 & 0 & 9 \\
\hline Belinois theuszi & 9 & 8 & 10 & 7 & 1 & 0 \\
\hline Belinois hedyle & 0 & 0 & 3 & 0 & 0 & 0 \\
\hline Catopsilla florella & 78 & 29 & 31 & 21 & 21 & 69 \\
\hline Catopsilla sp. & 42 & 7 & 16 & 5 & 9 & 16 \\
\hline Euronia cleodora & 0 & 0 & 1 & 0 & 0 & 0 \\
\hline Mylothris chloris & 56 & 71 & 34 & 23 & 1 & 8 \\
\hline Mylothris poppea & 34 & 9 & 27 & 5 & 1 & 19 \\
\hline Mylothris sp. & 51 & 12 & 10 & 4 & 0 & 6 \\
\hline Mylothris rhodope & 17 & 8 & 11 & 2 & 0 & 26 \\
\hline Charaxes varanes & 9 & 2 & 1 & 4 & 0 & 2 \\
\hline Charaxes protocrea & 2 & 1 & 1 & 0 & 0 & 0 \\
\hline Charaxes etheocles & 0 & 1 & 1 & 0 & 0 & 0 \\
\hline Charaxes brutus & 0 & 0 & 2 & 0 & 1 & 0 \\
\hline Charaxes tiridates & 5 & 1 & 3 & 0 & 0 & 0 \\
\hline Charaxes cynthia & 3 & 2 & 4 & 1 & 0 & 0 \\
\hline Charaxes zelica & 2 & 1 & 3 & 0 & 0 & 0 \\
\hline Euxanthe eurinome & 1 & 0 & 2 & 0 & 0 & 0 \\
\hline Castalius carana & 3 & 2 & 1 & 3 & 5 & 12 \\
\hline Lycaena helloides & 2 & 5 & 3 & 5 & 27 & 0 \\
\hline Lycaena sp. & 6 & 2 & 1 & 5 & 8 & 0 \\
\hline Meza indusiata & 0 & 3 & 1 & 0 & 8 & 0 \\
\hline Euchrysops albistriata & 5 & 8 & 11 & 3 & 39 & 25 \\
\hline Osmodes adon & 0 & 1 & 0 & 0 & 0 & 0 \\
\hline Spalgis lemolea & 0 & 1 & 1 & 0 & 0 & 0 \\
\hline Poecilmitis chrysaor & 0 & 0 & 1 & 0 & 0 & 0 \\
\hline Anthene sp. & 0 & 0 & 1 & 0 & 0 & 0 \\
\hline Pyrrhiades lucagus & 61 & 103 & 76 & 7 & 0 & 51 \\
\hline Amblyscirtis vialis & 3 & 2 & 3 & 0 & 1 & 0 \\
\hline Lerodea sp. & 4 & 3 & 2 & 1 & 0 & 0 \\
\hline Hesperia leonardus & 2 & 1 & 4 & 0 & 0 & 2 \\
\hline Hesperia sp. & 3 & 2 & 1 & 2 & 0 & 1 \\
\hline Oeneis polixenes & 2 & 3 & 6 & 1 & 0 & 0 \\
\hline Coliades chalyba & 0 & 0 & 3 & 0 & 0 & 0 \\
\hline
\end{tabular}

Table 2 gives the diversity indices for the butterfly species for the three sampling seasons. Yenku Block A (YBA) was the most important site for butterflies, with the highest numbers ( $N=1061$ and 1011 for July and June, resp.) and the highest species richness ( $S=106,111$, and 122 for July, January, and June, resp.), which was corroborated by the highest Margalef index $(d)$ of 15.07 in July, 16.85 in January, and 17.49 in June. Yenku Block B (YBB) had low butterfly species richness in June $(S=53)$ but relatively high abundance $(N=1064)$. YBB had the lowest abundance $(N=269)$ as well as a relatively low species richness $(S=41)$ in January corroborated by the lowest Margalef index (d) 7.15 (Table 2).

Yenku Block B (YBB) recorded a relatively lower evenness, $\left(J^{\prime}=0.7358\right)$ in July. The six species, Eurema brigitta, Papilio demodocus, Catopsilla florella, Acreae zetes, Phalanta phalanta, and Colotis antevippe, made up about $42 \%$ of the
TABLE 2: Calculation of suite of diversity indices for butterfly species collected from the two sites at Muni-Pomadze, Yenku Block A and Yenku Block B.

\begin{tabular}{lccccc}
\hline Sample site & $S$ & $N$ & $d$ & $J^{\prime}$ & $H^{\prime}$ (loge) \\
\hline YBAJUL & 106 & 1061 & 15.07 & 0.8547 & 3.986 \\
YBAJAN & 111 & 684 & 16.85 & 0.7554 & 3.558 \\
YBAJUN & 122 & 1011 & 17.49 & 0.8513 & 4.09 \\
YBBJUL & 60 & 825 & 8.786 & 0.7358 & 3.013 \\
YBBJAN & 41 & 269 & 7.15 & 0.8354 & 3.102 \\
YBBJUN & 53 & 1064 & 7.461 & 0.8602 & 3.415 \\
\hline
\end{tabular}

YBA: Yenku Block A; YBB: Yenku Block B; JUL: July; JAN: January; JUN: June; $S$ : species richness; $N$ : number of individuals; $d$ : Margalef's index; $J^{\prime}$ : Pielou's evenness index; $H^{\prime}$ : Shannon-Wiener index.
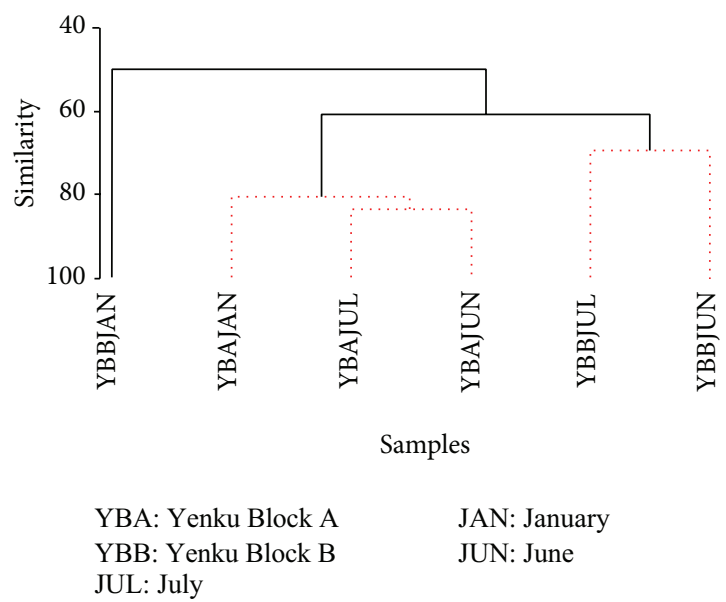

FIGURE 1: Dendrogram of butterfly species at the two sites in Winneba July (2011), January, and June, in 2012. The cluster analysis was performed using group-average linking on Bray-Curtis species similarity from fourth root transformed abundance data.

total numbers recorded at YBB in July. Both sites had a high evenness $\left(J^{\prime}>0.8354\right)$ in the wet (YBAJUL) and intermediate (YBBJUN) seasons (Table 2) with individuals evenly distributed among the different species. Yenku Block A (YBA) recorded a high diversity (Margalef index $d=16.85$ ) in January but with a low evenness $\left(J^{\prime}=0.7554\right)$ as a result of the dominance of $D$. chryssipus and Pyrrhiadis lucagus.

From the cluster analysis (Figure 1) the species population structure could be considered homogenous below a BrayCurtis similarity of $50 \%$. Homogeneity however begins to break down above $60 \%$, leading to the formation of two clusters of species communities: YBAJAN, YBAJUL, and YBAJUN forming one cluster and YBBJUL and YBBJUN forming the other.

Figure 2 is a dendrogram showing the relationships between butterfly species occurring at Muni-Pomadze that contributed abundance of 20 or more using group-average linking on Bray-Curtis species similarity from fourth root transformed abundance data. Above a Bray-Curtis similarity of $60 \%$ there is a formation of two clusters with more than 40 forming the main cluster which further breaks down into 
TABLE 3: Diversity indices for Odonata collected from the two sites at Muni-Pomadze, Yenku Block A and Yenku Block B.

\begin{tabular}{lccccc}
\hline Sample & $S$ & $N$ & $d$ & $J^{\prime}$ & $H^{\prime}$ (loge) \\
\hline YBAJUL & 7 & 77 & 1.381 & 0.7476 & 1.455 \\
YBBJUL & 10 & 68 & 2.133 & 0.8306 & 1.912 \\
YBAJAN & 7 & 69 & 1.417 & 0.6608 & 1.286 \\
YBBJAN & 5 & 26 & 1.228 & 0.8906 & 1.433 \\
YBAJUN & 8 & 44 & 1.85 & 0.776 & 1.614 \\
YBBJUN & 8 & 40 & 1.898 & 0.8874 & 1.845 \\
\hline
\end{tabular}

YBA: Yenku Block A; YBB: Yenku Block B; JUL: July; JAN: January; JUN: June; $S$ : species richness; $N$ : number of individuals; $d$ : Margalef's index; $J^{\prime}$ : Pielou's evenness index; $H^{\prime}$ : Shannon-Wiener index.

four distinct clusters around $73 \%$. Red-dotted lines indicate closely related species or species of close associations.

4.2. Dragonflies. Yenku Block B recorded the highest species richness $(S=10)$ for dragonflies in July which was corroborated by the highest Shannon-Wiener $(H=1.9)$ and Margalef $(d=2.1)$ indices. Dragonflies were most abundant in July $(N=77)$ at Yenku Block A with the lowest numbers recorded in January at Yenku Block B $(N=26)$ (Table 3$)$.

4.3. Other Insects. A total of 3720 insects belonging to 19 other insect orders were recorded from the traps. Diptera was the most abundant (1932) as well as the most diverse order with 36 families, followed by Coleoptera with 21 families and Hymenoptera with 13 families (Table 4).

The diversity indices for the total of 127 insect families caught in the traps are presented in (Table 5) to give a comparison for the two sampling sites. Yenku Block A recorded the highest family richness $(S=98)$ with a diversity $((d=14.97)$ and $(H=3.827))$ in June, but the lowest family richness $(S=41)$ and the lowest family diversity $(d=6.957)$ in January. Yenku Block B recorded the highest abundance of $N=1515$ with richness of $S=91$ in June. This was reduced to $N=227$ and $S=42$ in January. Insect diversity was the highest at both sites in June (intermediate season).

A cluster analysis using Bray-Curtis similarity was performed for all the insects collected from the traps at both sites for the three sampling seasons (Figure 3).

The insects were averaged over the orders and similarity analyses were performed on all 3720 insects from the 19 orders collected from the traps over the entire sampling period. The cluster analysis revealed three distinct clusters/groupings above a Bray-Curtis similarity 25\% (Figure 4) with homogeneity below a Bray-Curtis of $20 \%$, indicating, a high level of dissimilarity in distribution. This gives an indication of the evenness of the distributions of insect orders at the Ramsar site.

\section{Discussion}

5.1. Butterflies. 130 species of butterflies belonging to nine families were recorded during the survey. From the diversity indices for the butterfly species calculated for the three sampling seasons, the lowest abundance of butterflies at YBB
TABLE 4: Insects families recorded over the entire survey period.

\begin{tabular}{|c|c|c|c|c|c|c|}
\hline \multirow[b]{2}{*}{ Family } & \multicolumn{3}{|c|}{ Yenku Block A } & \multicolumn{3}{|c|}{ Yenku Block B } \\
\hline & July & January & June & July & January & June \\
\hline Gryllidae & 8 & 7 & 15 & 6 & 13 & 11 \\
\hline Acrididae & 6 & 6 & 4 & 7 & 5 & 14 \\
\hline Tettigonidae & 3 & 0 & 4 & 12 & 3 & 3 \\
\hline Tridactylidae & 0 & 2 & 5 & 0 & 1 & 4 \\
\hline Tetrigidae & 2 & 1 & 1 & 6 & 2 & 1 \\
\hline Formicidae & 81 & 96 & 31 & 75 & 39 & 29 \\
\hline Apidae & 6 & 0 & 8 & 4 & 1 & 5 \\
\hline Evaniidae & 1 & 3 & 1 & 3 & 1 & 1 \\
\hline Sphecidae & 2 & 2 & 5 & 0 & 1 & 8 \\
\hline Vespidae & 0 & 3 & 11 & 0 & 1 & 6 \\
\hline Braconidae & 3 & 7 & 13 & 8 & 6 & 15 \\
\hline Ichneumonidae & 2 & 2 & 4 & 4 & 1 & 3 \\
\hline Scelionidae & 0 & 3 & 2 & 1 & 2 & 1 \\
\hline Halictidae & 0 & 1 & 2 & 2 & 1 & 1 \\
\hline Pompylidae & 1 & 0 & 4 & 0 & 0 & 3 \\
\hline Chalcididae & 0 & 2 & 2 & 0 & 1 & 4 \\
\hline Eulophidae & 1 & 0 & 3 & 0 & 2 & 4 \\
\hline Tiphiidae & 2 & 0 & 1 & 0 & 0 & 0 \\
\hline Blattidae & 6 & 5 & 9 & 1 & 4 & 1 \\
\hline Mantidae & 2 & 0 & 1 & 0 & 0 & 1 \\
\hline Noctuidae & 3 & 4 & 2 & 0 & 0 & 4 \\
\hline Arctidae & 0 & 1 & 0 & 1 & 0 & 2 \\
\hline Satyridae & 2 & 0 & 2 & 0 & 0 & 3 \\
\hline Pieridae & 0 & 0 & 3 & 1 & 1 & 2 \\
\hline Acraeidae & 0 & 0 & 1 & 1 & 0 & 0 \\
\hline Nymphalidae & 0 & 1 & 2 & 2 & 0 & 0 \\
\hline Termitidae & 1 & 1 & 2 & 0 & 2 & 5 \\
\hline Rhinotermitidae & 0 & 0 & 1 & 0 & 0 & 2 \\
\hline Kalotermitidae & 2 & 0 & 0 & 0 & 0 & 1 \\
\hline Cercopidae & 5 & 11 & 6 & 10 & 26 & 8 \\
\hline Aleyrodidae & 0 & 2 & 4 & 0 & 0 & 0 \\
\hline Aphididae & 0 & 0 & 3 & 0 & 0 & 0 \\
\hline Fulgoridae & 0 & 0 & 1 & 0 & 0 & 0 \\
\hline Cicadellidae & 2 & 3 & 13 & 17 & 9 & 13 \\
\hline Delphacidae & 0 & 0 & 2 & 3 & 2 & 2 \\
\hline Membracidae & 0 & 1 & 0 & 0 & 0 & 1 \\
\hline Pseudococcidae & 0 & 0 & 1 & 0 & 0 & 1 \\
\hline Dictyopharidae & 1 & 0 & 0 & 2 & 0 & 1 \\
\hline Psyllidae & 0 & 0 & 3 & 0 & 3 & 4 \\
\hline Acanalonidae & 1 & 0 & 0 & 0 & 0 & 1 \\
\hline Flatidae & 0 & 0 & 1 & 0 & 0 & 0 \\
\hline Isotomidae & 3 & 33 & 22 & 1 & 32 & 27 \\
\hline Calliphoridae & 2 & 2 & 5 & 31 & 2 & 3 \\
\hline Sepsidae & 0 & 0 & 3 & 5 & 0 & 0 \\
\hline Tachinidae & 4 & 5 & 13 & 0 & 12 & 19 \\
\hline Sarcophagidae & 3 & 1 & 15 & 1 & 3 & 6 \\
\hline Culicidae & 1 & 5 & 8 & 34 & 6 & 17 \\
\hline Muscidae & 2 & 1 & 9 & 3 & 1 & 7 \\
\hline
\end{tabular}


TABLE 4: Continued.

\begin{tabular}{|c|c|c|c|c|c|c|}
\hline \multirow[b]{2}{*}{ Family } & \multicolumn{3}{|c|}{ Yenku Block A } & \multicolumn{3}{|c|}{ Yenku Block B } \\
\hline & July & January & June & July & January & June \\
\hline Tephritidae & 69 & 24 & 29 & 4 & 5 & 22 \\
\hline Drossophilidae & 1 & 53 & 24 & 3 & 5 & 993 \\
\hline Phoridae & 11 & 14 & 24 & 7 & 15 & 28 \\
\hline Tipulidae & 4 & 0 & 2 & 0 & 0 & 3 \\
\hline Asilidae & 0 & 0 & 2 & 7 & 0 & 4 \\
\hline Diopsidae & 0 & 0 & 0 & 0 & 0 & 1 \\
\hline Dolichopodidae & 1 & 1 & 2 & 9 & 0 & 4 \\
\hline Syrrphidae & 2 & 1 & 7 & 5 & 2 & 10 \\
\hline Rhagionidae & 0 & 0 & 1 & 0 & 0 & 3 \\
\hline Stratiomyiidae & 0 & 0 & 2 & 0 & 0 & 1 \\
\hline Bombylidae & 2 & 0 & 2 & 1 & 0 & 1 \\
\hline Tabanidae & 19 & 0 & 28 & 1 & 0 & 3 \\
\hline Glossinidae & 1 & 0 & 92 & 0 & 0 & 8 \\
\hline Simulidae & 2 & 0 & 0 & 3 & 0 & 1 \\
\hline Mycetophilidae & 0 & 0 & 4 & 0 & 0 & 9 \\
\hline Sciaridae & 0 & 0 & 2 & 0 & 0 & 6 \\
\hline Chironomidae & 0 & 0 & 0 & 3 & 0 & 1 \\
\hline Ceratopogonidae & 0 & 0 & 3 & 0 & 0 & 2 \\
\hline Conopidae & 0 & 0 & 2 & 3 & 0 & 0 \\
\hline Lauxanidae & 0 & 0 & 0 & 0 & 0 & 2 \\
\hline Psychodidae & 0 & 0 & 1 & 0 & 0 & 0 \\
\hline Cecidomyiidae & 1 & 0 & 2 & 0 & 0 & 0 \\
\hline Platypezidae & 0 & 0 & 1 & 0 & 0 & 0 \\
\hline Trichoceridae & 0 & 0 & 1 & 0 & 0 & 4 \\
\hline Acroceridae & 0 & 0 & 0 & 0 & 0 & 2 \\
\hline Empididae & 0 & 0 & 2 & 13 & 0 & 18 \\
\hline Therevidae & 1 & 0 & 3 & 0 & 3 & 1 \\
\hline Otitidae & 0 & 0 & 12 & 0 & 0 & 3 \\
\hline Anthomyiidae & 0 & 0 & 0 & 8 & 0 & 11 \\
\hline Bibionidae & 0 & 0 & 0 & 7 & 0 & 3 \\
\hline Chrysomelidae & 11 & 3 & 12 & 19 & 2 & 8 \\
\hline Carabidae & 23 & 0 & 14 & 8 & 4 & 2 \\
\hline Tenebrionidae & 3 & 1 & 6 & 1 & 0 & 0 \\
\hline Scarabaeidae & 167 & 0 & 44 & 2 & 0 & 2 \\
\hline Mordellidae & 5 & 0 & 1 & 8 & 1 & 1 \\
\hline Phalacridae & 0 & 0 & 2 & 0 & 0 & 1 \\
\hline Coccinellidae & 2 & 0 & 0 & 0 & 3 & 0 \\
\hline Dermestidae & 0 & 0 & 0 & 4 & 0 & 0 \\
\hline Meloidae & 0 & 0 & 0 & 3 & 0 & 0 \\
\hline Curcujidae & 0 & 1 & 6 & 0 & 0 & 14 \\
\hline Scolytidae & 0 & 0 & 1 & 1 & 0 & 0 \\
\hline Lampyridae & 0 & 0 & 5 & 13 & 0 & 2 \\
\hline Staphylinidae & 5 & 0 & 15 & 52 & 0 & 51 \\
\hline Ptinidae & 0 & 0 & 1 & 0 & 0 & 1 \\
\hline Lucanidae & 0 & 0 & 2 & 0 & 0 & 1 \\
\hline Hesteridae & 0 & 0 & 2 & 0 & 0 & 0 \\
\hline Anthicidae & 0 & 0 & 0 & 0 & 0 & 1 \\
\hline Cleridae & 0 & 0 & 0 & 0 & 0 & 1 \\
\hline
\end{tabular}

TABLE 4: Continued.

\begin{tabular}{lcccccc}
\hline & \multicolumn{3}{c}{ Yenku Block A } & \multicolumn{3}{c}{ Yenku Block B } \\
Family & July & January & June & July & January & June \\
\hline Scaphididae & 0 & 0 & 2 & 0 & 0 & 0 \\
Curculionidae & 5 & 0 & 6 & 1 & 0 & 6 \\
Cerambycidae & 1 & 0 & 1 & 0 & 0 & 2 \\
Hydropsychidae & 5 & 0 & 3 & 14 & 0 & 4 \\
Polycentropodidae & 3 & 0 & 0 & 0 & 0 & 5 \\
Philopotamidae & 0 & 0 & 1 & 4 & 0 & 0 \\
Leptoceridae & 2 & 0 & 1 & 10 & 0 & 2 \\
Psychomyiidae & 0 & 0 & 0 & 2 & 0 & 0 \\
Thripidae & 2 & 0 & 7 & 7 & 1 & 13 \\
Forfinculidae & 1 & 0 & 2 & 0 & 0 & 1 \\
Labiidae & 0 & 0 & 2 & 0 & 1 & 0 \\
Carcinophoridae & 0 & 1 & 1 & 0 & 0 & 2 \\
Libellulidae & 1 & 0 & 2 & 0 & 0 & 1 \\
Coenagrionidae & 0 & 0 & 0 & 0 & 0 & 1 \\
Pyrrhocoridae & 1 & 1 & 3 & 2 & 0 & 3 \\
Coreidae & 1 & 0 & 1 & 2 & 0 & 0 \\
Pentatomidae & 3 & 1 & 3 & 1 & 0 & 2 \\
Reduvidae & 0 & 1 & 3 & 1 & 2 & 1 \\
Lygaeidae & 0 & 0 & 2 & 1 & 1 & 2 \\
Berytidae & 0 & 1 & 1 & 0 & 0 & 0 \\
Largidae & 2 & 0 & 0 & 0 & 1 & 1 \\
Nepidae & 0 & 0 & 0 & 1 & 0 & 0 \\
Alydidae & 0 & 0 & 1 & 1 & 0 & 0 \\
Cydnidae & 1 & 0 & 2 & 0 & 0 & 1 \\
Thyreocoridae & 1 & 0 & 1 & 0 & 0 & 2 \\
Ascalaphidae & 0 & 0 & 1 & 0 & 0 & 0 \\
Sialidae & 0 & 0 & 0 & 1 & 0 & 0 \\
Phasmatidae & 1 & 0 & 3 & 0 & 0 & 1 \\
Oligotomidae & 0 & 0 & 1 & 0 & 0 & 0 \\
Machilidae & 0 & 0 & 0 & 0 & 0 & 1 \\
Panorpidae & 0 & 0 & 0 & 0 & 0 & 1 \\
\hline & & & & & &
\end{tabular}

TABLE 5: Diversity indices for insect families collected from the two sites at Muni-Pomadze, Yenku Block A and Yenku Block B.

\begin{tabular}{lccccc}
\hline Sample & $S$ & $N$ & $d$ & $J^{\prime}$ & $H^{\prime}$ (loge) \\
\hline YBAJUL & 59 & 513 & 9.294 & 0.6544 & 2.668 \\
YBAJAN & 41 & 314 & 6.957 & 0.694 & 2.577 \\
YBAJUN & 98 & 651 & 14.97 & 0.8347 & 3.827 \\
YBBJUL & 63 & 472 & 10.07 & 0.8245 & 3.416 \\
YBBJAN & 42 & 227 & 7.558 & 0.8075 & 3.018 \\
YBBJUN & 91 & 1515 & 12.29 & 0.4405 & 1.987 \\
\hline
\end{tabular}

YBA: Yenku Block A; YBB: Yenku Block B; JUL: July; JAN: January; JUN: June; $S$ : species richness; $N$ : number of individuals; $d$ : Margalef's index; $J^{\prime}$ : Pielou's evenness index; $H^{\prime}$ : Shannon-Wiener index.

in January $(N=269)$ as well as a relatively low species richness $(S=41)$ corroborated by the lowest Margalef index (d) 7.15 can be attributed to the fact that in January most of the vegetation covers at Yenku Block B (YBB) had been removed by burning, a common practice for that time of the year. This 
was in contrast to a study on butterflies of two sacred grooves in the Eastern Region of Ghana carried out by Nganso et al. [23] which reported that butterflies were more speciose and diverse in the dry season most probably due to higher temperatures.

The low evenness $\left(J^{\prime}=0.7358\right)$ at YBB in July can be attributed to the dominance of Eurema brigitta, Papilio demodocus, Catopsilla florella, Acreae zetes, Phalanta phalanta, and Colotis antevippe which constituted about $42 \%$ of the total numbers recorded at YBB. These are typically open country, grassland species, and their dominance at Yenku Block B was not surprising given the open nature of the vegetation which allows for free flight and easy movement.

Factors such as resource availability for adults and larval host plants, behavioural traits, and interaction with other species [21] may explain the increase in butterfly richness and diversity during the dry season at YBA. This underscores the importance of measuring and documenting local conditions as part of studies to determine species composition, even though these factors were not adequately measured in this survey.

Although Yenku Block A (YBA) recorded a high diversity (Margalef index $d=16.85$ ) in January, its low evenness $\left(J^{\prime}=0.7554\right)$ was due to the dominance of Danaus chryssipus and Pyrrhiadis lucagus. Pyrrhiades lucagus, a fast flier from the family Hesperiidae was observed in large numbers along the fringes of the forest and also in the Teak and Acacia plantations at Yenku Block A, most probably feeding on the nectar from their flowers. D. chryssipus, though an open savannah species, was found in large numbers at Yenku Block A where portions of the Eucalytus plantation had been cut down and converted to maize and cassava farmlands, providing adequate food resources as well as pockets of open areas for easy flight for these species. Their larvae feed on milkweed (Asclepias spp.) and other related species.

The species population structure could be considered homogenous, below a Bray-Curtis similarity of about 53\%, however, homogeneity begins to break down leading to the formation of two clusters of species communities around 58\%: YBBJUL, YBAJUL, YBAJUN, and YBBJUN forming one cluster and YBAJAN and YBBJAN forming the other (Figure 1). From the cluster analysis Pyrrhiades lucagus, Danaus chrysippus, Mylothris chloris, Belinois calypso, and Catopsilla florella, for example, (linked by red-dotted lines) cluster above a Bray-Curtis similarity of $80 \%$ (Figure 2). Each of these five species was recorded in excess of 150 individuals. They have similar behavioural traits and most feed on the same or related plant species and so their clustering together is to be expected.

Species of butterflies such as Papilio demodocus, P. nireus, Junonia oenone, and J. terea are known to be now much more common in West Africa than they ever were due to the widespread destruction and fragmentation of forest cover that has taken place in this part of Africa [24]. They are specialized in degraded habitats and open spaces and very few would ever be met within forest of good condition. Papillio demodocus was observed in large numbers in the open grassland areas and also along the beach close to the Muni Lagoon. Junonia oenone, for example, though common to both sites, was recorded mainly as singletons at Yenku Block A but in much larger numbers in the thickets and grasslands along the coastal villages of Mankoaze and Akosua which were sampled as part of Yenku Block B. The presence of these species, especially at Yenku Block A, is therefore a clear indication of the forest degradation that has taken place at this site and thus can be considered as clear-cut indicator species of forest disturbance. In theory, these species are known to be generally common to have fairly wide ranges and to colonize both intact and disturbed forests [6]. The high numbers especially of $J$. terea and $P$. nireus recorded at Yenku Block A also suggest that the degraded forest at Yenku Block A is not in a particularly good shape.

Species common to both sites were Phalanta phalanta, Acraea zetis, Danaus chryssipus, Eurema brigitta (which was the second most abundant species recorded), Catopssila florella, Colotis evippe and Colotis antevippe. Species such as Nepheronia thalassina, Nepheronia argia, Belinois calypso, Mylothris chloris, and Mylothris poppea, though common to both sites, were more abundant at Yenku Block A, a degraded natural forest interspersed with pockets of farmlands, Eucalyptus, Teak, and Acacia plantations with a few thickets of dense shrubs. These species are commonly found in African woodlands.

Satyrids are generally dusty to dark brown and blend well with the dark vegetation of forested areas and forest undergrowths and are associated with grasses. Species such as Bicyclus safitza and B. zinebi which are associated with woodland and forests throughout Africa [15] were recorded in relatively larger numbers at Yenku Block A. The increased presence of grass-feeding Satyrine species is an apparent sign of forest disturbance [24]. Grasses are generally uncommon on the Afrotropical forest floor [25] but can colonize and spread in abundance when light penetration into the forest proper increases as a result of, for example, increased edge to interior habitat or degradation of the forest canopy [26]. This coupled dynamic between grasses and Satyrines also signals the high potential of this group as indicators of forest condition, an attribute that could be beneficially exploited to help direct limited conservation resources in economically disadvantaged countries, for example, to identify priority sites for formal protection or to steer restoration efforts [26].

Most of the eight species of Euphaedra such as E. crockeri and E. eleus were found along footpaths deep in the forests of Yenku Block A. Nepheronia spp. are high fast fliers which can be seen darting in and out of the top of trees and so were recorded in larger numbers at Yenku Block A which had more trees than Yenku Block B, a more grassland open area.

The Lycaenids such as Lycaena helloides, Castalius carana, and Euchrysops albistriata were found around drying puddles of water and along paths and roads in relatively larger numbers at Yenku Block B. Most of these butterflies are associated with ants that were abundant in the sampled areas.

5.2. Odonata. Dragonflies are relatively ever-present in freshwater wetlands, and occupy a critical trophic niche in these systems. The adults are easily sampled; they are insects that are susceptible to human disturbance and constitute good candidates for wetlands assessment [27]. Dragonflies can 


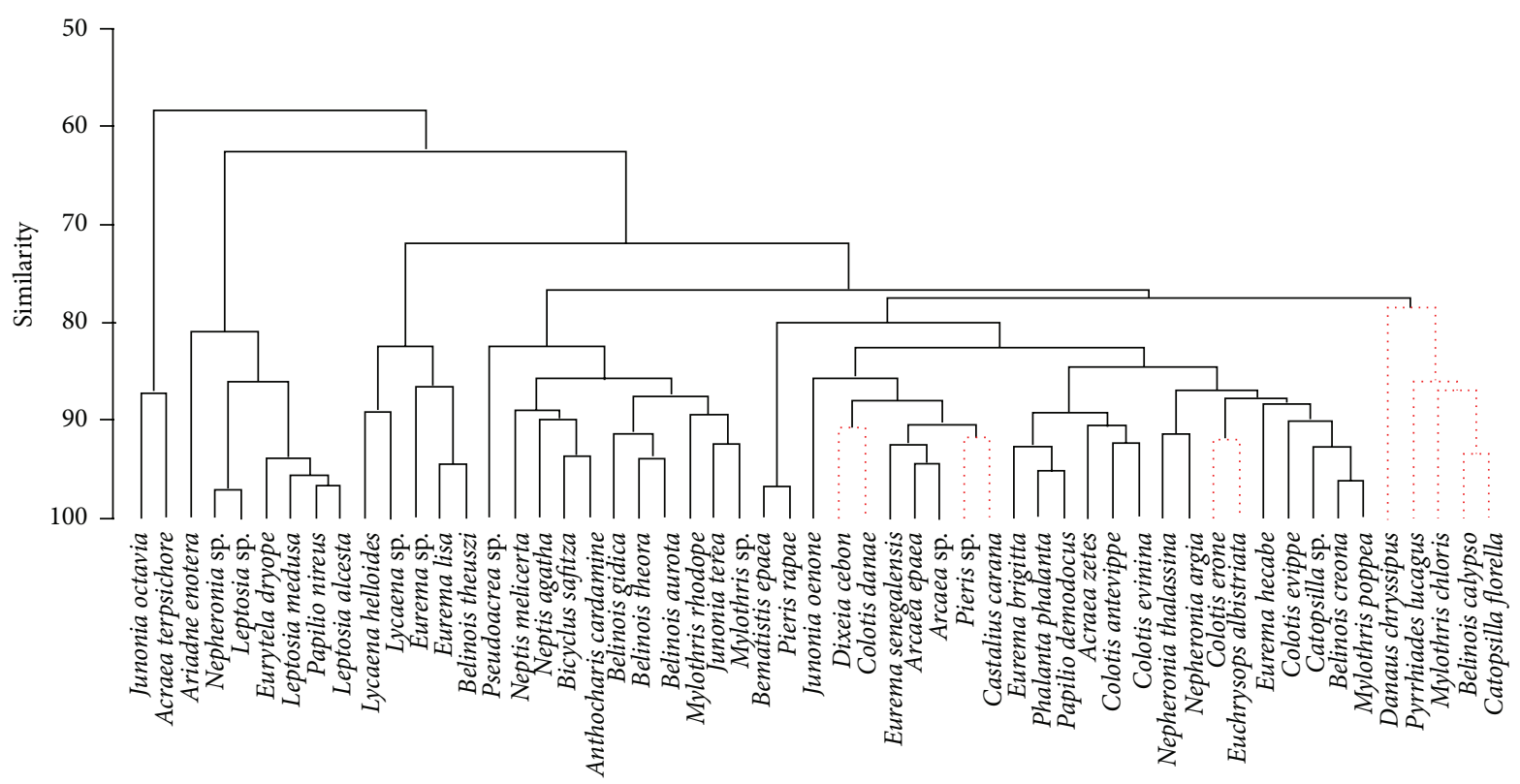

Samples

FIGURE 2: Dendrogram of butterfly species occurring at Muni-Pomadze using group-average linking on Bray-Curtis species similarity from fourth root transformed abundance data. The analysis was performed on species contributing abundance of 20 or more.

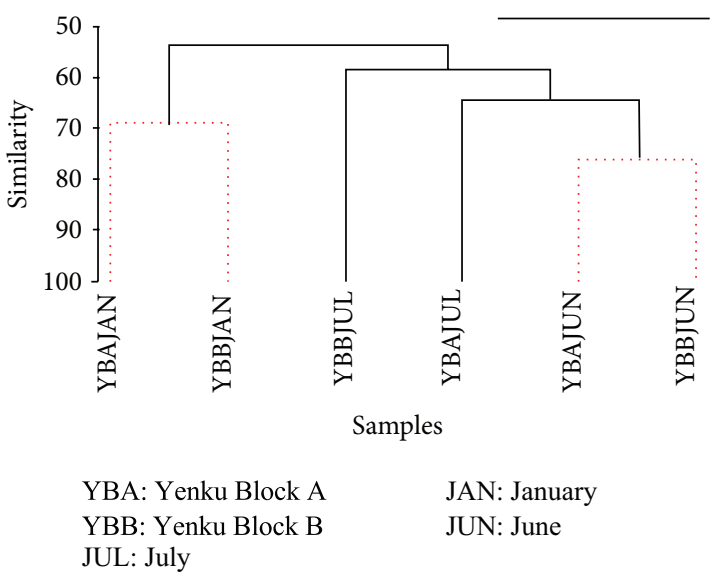

FIGURE 3: Dendrogram of all other insects collected from traps at the two sites in Winneba (YBA and YBB) in July (2011), January, and June, in 2012. The cluster analysis was performed using group-average linking on Bray-Curtis similarity from fourth root transformed abundance data.

serve as biological indicators of environmental health [28$30]$. According to [1] vegetation covering can lead to a decline in population of adult dragonflies or, in contrast, cause an increase in the species diversity according to Clark and Samways [31] and Acquah-Lamptey et al. [28].

All the dragonfly species recorded in Yenku Blocks A and $\mathrm{B}$ are widespread species and therefore classified as of least concern [32]. The presence of species such as Pantala

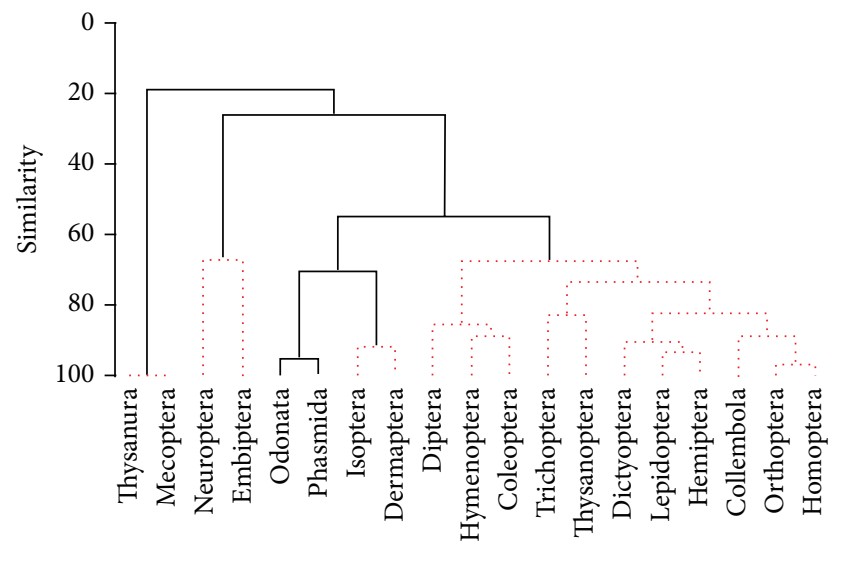

FIGURE 4: Dendrogram of all insect orders collected from traps at the two sites (YBA and YBB) in July (2011), January, and June, in 2012. The cluster analysis was performed using group-average linking on Bray-Curtis similarity from fourth root transformed abundance data.

flavescens and Tramea basilaris indicate open areas or nearness to open areas, whereas the presence of Phoan iridipennis infer that the area it occurred in is adequately shaded, occurring especially in gallery forests [33]. Crocothemis erythreae is an open area species and usually prefers areas close to large water bodies which was the case at YBB. Palpopleura lucia and Orthetrum julia are known to be widespread and very 
common species; hence the high abundance recorded in this study was expected.

5.3. Other Insects. A total of 3720 insects belonging to 19 orders were recorded from the traps. Diptera was the most abundant (1932) as well as the most diverse order with 36 families, followed by Coleoptera with 21 families and Hymenoptera with 13 families. The high numbers of Dipterans may have resulted from the use of the Malaise traps and the flight interception traps employed in this study which are basically designed to trap small flying insects, mainly Diptera and Hymenoptera. They were set up close to streams and many of the insects recorded were aquatic species that may have been trapped on emergence or as they came to lay eggs in or close to the water. Flight interception traps are also designed to intercept the flight of small to medium-sized flying insects. In a baseline survey conducted in 1997 [8], 3151 insects belonging to 15 orders were recorded with Coleoptera, being the most abundant order (1258 individuals) followed by Hymenoptera (716) and Lepidoptera (416 individuals).

Insect diversity was the highest at both sites in June (intermediate season) most probably because, during this time of the year, there are ample food resources for the insects and rainfall is not too heavy since heavy rainfall sweeps most insects away and destroys many of their food resources. The high numbers of Dipterans accounted for the highest abundance $(N=1515)$ and the lowest evenness $\left(J^{\prime}=0.4405\right)$ at Yenku Block B in June. Most of the Dipterans sampled were aquatic and at this time of the year water levels are just right for them whereas during the wet season most of these Dipterans as well as other aquatic insects are swept away or dislodged during the heavy rains.

From the cluster analysis the insect species composition at Yenku Blocks A and B had a fairly similar species distribution for June and July (Figure 3). There was a distinct cluster of species communities for both Yenku Blocks A and B in January indicating similar species composition and distribution, as was the case for the butterfly species composition, the burning that had occurred during the dry season accounted for the low numbers and diversity at both sites during the January sampling. The dominance of Hymenoptera, Diptera, Collembola, Orthoptera, and Homoptera at both sampling sites in January may explain the similarity.

The cluster analysis performed on the insect orders revealed three distinct clusters/groupings above a Bray-Curtis similarity $25 \%$ with homogeneity below a Bray-Curtis of $20 \%$, indicating a high level of dissimilarity in distribution (Figure 4). It is not surprising that Thysanura and Mecoptera form outside the three main clusters since they have a similar distribution spending most or part of their life cycle in moist decaying vegetation and soil. Thysanura are among the most primitive of all insects.

It is interesting to note that Diptera, Hymenoptera, and Coleoptera cluster together around 95\% indicating a high level of similarity in distribution. These three orders contributed to $81 \%$ of the entire insect collection from the traps at both sites.

The presence of dung beetles, Scarabaeidae, in large numbers at Yenku Block A during the wet season sampling is an indication of the presence of large mammals at this site which is typical for the kind of vegetation found at the site.

5.4. Changes in Insect Species Composition over the Twenty Years of Site Designation as a Ramsar Site. The total number of species recorded in the current study and composition of the various taxonomic groups suggest an increase in insect abundance when compared with the findings in the 1997 survey. However, with the exception of butterflies, a direct comparison of overall insect abundance recorded in the two studies would not be appropriate because of the limited range of techniques and different sampling methods used in the 1997 study. The sampling methods used for butterflies in the two studies were similar and therefore the results are comparable. 74 ( $57 \%$ of the total) butterfly species were common to both Yenku Blocks A and B in this survey as compared to 22 species (29.3\% of the total) that were common to both sites in 1997 [8]. 56 species ( $43 \%$ of the total) were recorded only in Yenku Block A compared to 32 species (42.6\% of the total) in 1997. The 130 species of butterflies from 9 families recorded in the current survey is an increase from the 75 species from five families recorded during the 1997 baseline survey [8]. Species such as Charaxes fulvescens, Graphium adamastor, Belinois ianthe, and Bebearia sophus were recorded in the 1997 survey but not in the current survey. Many species belonging to the genera Belinois, Mylothris, Eurema, Euphaedra, Colotis, and Acraea look similar in flight and can only be properly identified when captured and critically examined. The fewer number of those species recorded by Gordon and Cobblah [8] may therefore be accounted for by the fact that their records may have been based mostly on insects observed in flight and hence the possibility of mixing up these species.

No butterfly species were recorded only in Yenku Block $\mathrm{B}$ in the current survey; however Gordon and Cobblah [8] recorded two species (2.7\% of the total) that were found only at Mankoadze (Yenku Block B) in 1997. Gordon and Cobblah [8] state that several of the butterfly species such as Papilio demodocus, P. nireus, Neptis morosa, Bicyclus safitza, and Charaxes varanes recorded at Mankoadze (Yenku Block B) were strongly associated with thickets. However in the current study, P. nireus was not recorded at Yenku Block $B$ but was rather observed in relatively large numbers at Yenku Block A darting between the Acacia trees and the open fields that had been cultivated with maize and cassava. Neptis merosa was recorded only as a singleton at Yenku Block B.

Many habitat changes had occurred at the Ramsar site since its designation in 1992. The presence of pockets of farmlands created from portions of the Eucalytus plantation within Yenku Block A that had been cut down and converted to maize and cassava farmlands, for example, had created a wider range of habitat types and adequate food resources as well as pockets of open areas for easy flight allowing for the colonization of more butterfly species. At the initial stages of habitat loss, new habitats occur as gaps within the original habitat; however, as the proportion of new habitats increases in the landscape, the remaining areas of original habitat will be smaller and more isolated from one another [34]. 


\section{Conclusion}

The survey revealed high levels of insect diversity at the MuniPomadze Ramsar site with 134 insect families belonging to 19 orders recorded, including 130 species of butterflies. Butterfly species richness was greater at Yenku Block A (130) than at Yenku Block B (74). As was the case in a survey conducted in 1997 [35], there were clear differences in butterfly fauna of the two sites which represented somewhat different habitats. These differences indicate a fine grained response by the butterfly communities to habitat changes and confirm the suggestion by [8] that butterfly monitoring at Muni would provide useful ecological indicator data to compliment those of mammals, birds, and plant species monitoring.

Species such as Junonia oenone, J. terea, Papillio nireus, and $P$. demodocus are specialized in degraded habitats and open spaces and very few would ever be met within forest of good condition. Their presence especially at Yenku Block $\mathrm{A}$ in relatively large numbers is a clear indication of forest degradation (the result of the conversion of parts of the forest into farmlands).

The presence of deep forest species such as Salamis anacardii, Euphaedra crokeri, Charaxes tiridatus, Hypolimnas salmacis, and Diestogina feronia however is welcome news and an indication that some parts of this reserve are still in good shape. Obviously, the forests areas at Muni-Pomadze serve as refuges for displaced species from areas where farming and other human activities have disturbed these insects.

The Muni-Pomadzi Ramsar site is still in a relatively good condition although more efforts should be put in place by the Forestry Commission of Ghana to maintain it and prevent encroachment by farmers and loggers since it is a site for conservation not only in Ghana but also in West Africa.

\section{Conflict of Interests}

All authors agree to the publication of this paper and they do not have any conflict of interests with any party or commercial identity. They have no involvement that might raise questions of bias in this reported work or in its conclusions, implications, or opinions.

\section{Acknowledgments}

This study was undertaken under the building capacity to meet the climate change challenge (B4C) - Ghana project, which is implemented by a consortium of three institutions, the University of Ghana (lead), the Centre for African Wetlands, and the Ghana Wildlife Society, with funding from the Open Society Foundations. The authors are grateful to the Open Society Foundations for the funds that made the study possible.

\section{References}

[1] P. J. Gullan and P. S. Cranston, Insects: An Outline of Entomology, Chapman and Hall, 2010.

[2] S. K. Raina, T. P. S. Chauhan, M. K. Tayal, R. K. Pandey, and R. Mohan, "Multiple silkworm cocoon cropping in jammu division," in Proceedings of the Workshop on Recent Trends in Development of Sericulture in Jammu and Kashmir, pp. 63-67, Jammu and Kashmir, India, 2011.

[3] W. Buchs, Biotic Indicators for Biodiversity and Sustainable Agriculture, Elsevier Science, 2003.

[4] D. D. Hart and R. J. Horwitz, "Habitat diversity and the speciesarea relationship: alternative models and tests," in Habitat Structure: The Physical Arrangement of Objects in Space, S. S. Bell, E. D. McCoy, and H. R. Mushinsky, Eds., pp. 47-68, Chapman and Hall, London, UK, 1991.

[5] J. C. Moore and P. C. de Ruiter, "Compartmentalization of resource utilization within soil ecosystems," in Multitrophic Interactions in Terrestrial Ecosystems, A. C. Gange and V. K. Brown, Eds., pp. 375-393, Blackwell Science, Oxford, UK, 1997.

[6] A. E. Magurran, Ecological Diversity and Its Measurement, Croom Helm, London, UK, 1988.

[7] P. Dennis, M. R. Young, and I. J. Gordon, "Distribution and abundance of small insects and arachnids in relation to structural heterogeneity of grazed, indigenous grasslands," Ecological Entomology, vol. 23, no. 3, pp. 253-264, 1998.

[8] I. Gordon and M. Cobblah, "Insects of the Muni-Pomadze Ramsar site," Biodiversity and Conservation, vol. 9, no. 4, pp. 479-486, 2000.

[9] K.-D. B. Dijkstra and V. Clausnitzer, "The dragonflies and damselflies of eastern Africa: handbook for allOdonata from Sudan to Zimbabwe," Studies in Afrotropical Zoology. In press.

[10] D. Carter, Butterflies and Moths, Stoddart Publishing, 1998.

[11] P. J. Gullan and P. S. Cranston, The Insects: An Outline of Entomology, Blackwell, Malden, Mass, USA, 2005.

[12] C. H. Scholtz and E. Holm, Insects of Southern Africa, Butterworths Professional Publishers, 1989.

[13] M. Chinery, Insects of Britain and Northern Europe, Harper Collins Publishers, 1993.

[14] M. Chinery, Butterflies and Moths, Photoguide, Harper Collins Publishers, 1995.

[15] R. H. Carcasson, Collins Handguide to the Butterflies of Africa, William Collins Sons, 1981.

[16] R. A. Crowson, Coleoptera: Introduction and Key to Families. HIBI Vol. 4, 1956.

[17] C. Belcastro and T. B. Larsen, "Butterflies as an indicator group for the conservation value of the Gola forests in Sierra Leone," Report To the Gola Forest Conservation Concession Project, 2006.

[18] T. B. Larsen, Butterflies of West Africa, vol. 2, Apollo Books, 2005.

[19] P. L. Miller, Dragonflies, Richmond Publishers, Slough, UK, 1987.

[20] G. C. McGavin, Insects, Spiders and other Terrestrial Arthropods, Dorling Kindersley, 2002.

[21] C. E. G. Pinheiro and J. V. C. Ortiz, "Communities of fruitfeeding butterflies along a vegetation gradient in central Brazil," Journal of Biogeography, vol. 19, no. 5, pp. 505-511, 1992.

[22] A. E. Magurran, Measuring Biological Diversity, Blackwell Publishing, Oxford, UK, 2004.

[23] B. T. Nganso, R. Kyerematen, and D. Obeng-Ofori, "Diversity and abundance of butterfly species in the abiriw and odumante sacred groves in the Eastern Region of Ghana," Research in Zoology, vol. 2, no. 5, pp. 38-46, 2012.

[24] T. B. Larsen, "The Butterflies of Ghana: their Implications for Conservation and Sustainable Use," Report To IUCN and Department of Game and Wildlife, 1994. 
[25] D. F. Owen, Tropical Butterflies: The Ecology and Behaviour of Butterflies in the Tropics with Special Reference To African Species, Clarendon Press, London, UK, 1971.

[26] J. L. Bossart, E. Opuni-Frimpong, S. Kuudaar, and E. Nkrumah, "Richness, abundance, and complementarity of fruit-feeding butterfly species in relict sacred forests and forest reserves of Ghana," Biodiversity and Conservation, vol. 15, no. 1, pp. 333359, 2006.

[27] J. T. Bried, Community and Conservation Ecology of Dragonfly and Damselfly Adults in Mississippi Wetlands [Thesis], Mississippi State University, 2005.

[28] D. Acquah-Lamptey, R. Kyerematen, and E. O. Owusu, "Using Odonates as markers of the environmental health of water and its land related ecotone," International Journal of Biodiversity and Conservation, vol. 5, no. 11, pp. 761-769, 2013.

[29] Z. S. Ameilia, M. R. Che Salmah, and A. Abu Hassan, "Distribution of Dragonfly (Odonata: Insecta) in the Kerian River Basin, Kedah-Perek, Malaysia," USU Repository, 2006.

[30] V. Clausnitzer, "Dragonfly communities in coastal habitats of Kenya: indication of biotope quality and the need of conservation measures," Biodiversity and Conservation, vol. 12, no. 2, pp. 333-356, 2003.

[31] T. E. Clark and M. J. Samways, "Dragonflies (Odonata) as indicators of biotope quality in the Kruger National Park, South Africa," Journal of Applied Ecology, vol. 33, no. 5, pp. 1001-1012, 1996.

[32] IUCN, “IUCN Red List of Threatened Species," Version 2012. 2, 2012, http://www.iucnredlist.org/.

[33] V. Clausnitzer, K.-D. B. Dijkstra, and F. Suhling, "Phaon iridipennis IUCN, 2012," IUCN Red List of Threatened Species, version 2012. 2, 2012, http://www.iucnredlist.org/.

[34] H. Andren, "Habitat fragmentation and changes in biodiversity," Ecological Bulletins, vol. 46, pp. 171-181, 1997.

[35] C. Gordon, Y. Ntiamoa-Baidu, and J. M. Ryan, "The MuniPomadze Ramsar site," Biodiversity and Conservation, vol. 9, no. 4, pp. 447-464, 2000. 

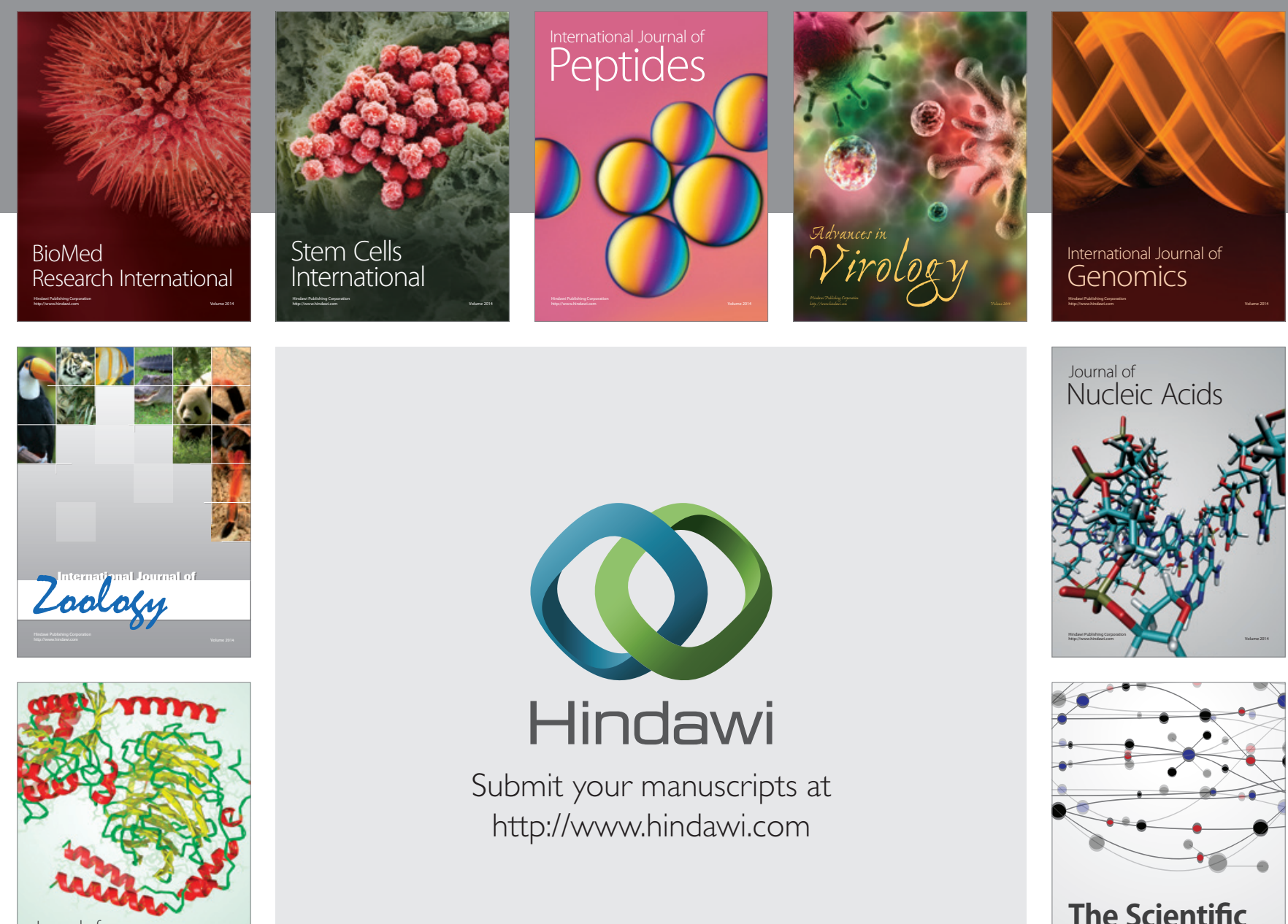

Submit your manuscripts at

http://www.hindawi.com

Journal of
Signal Transduction
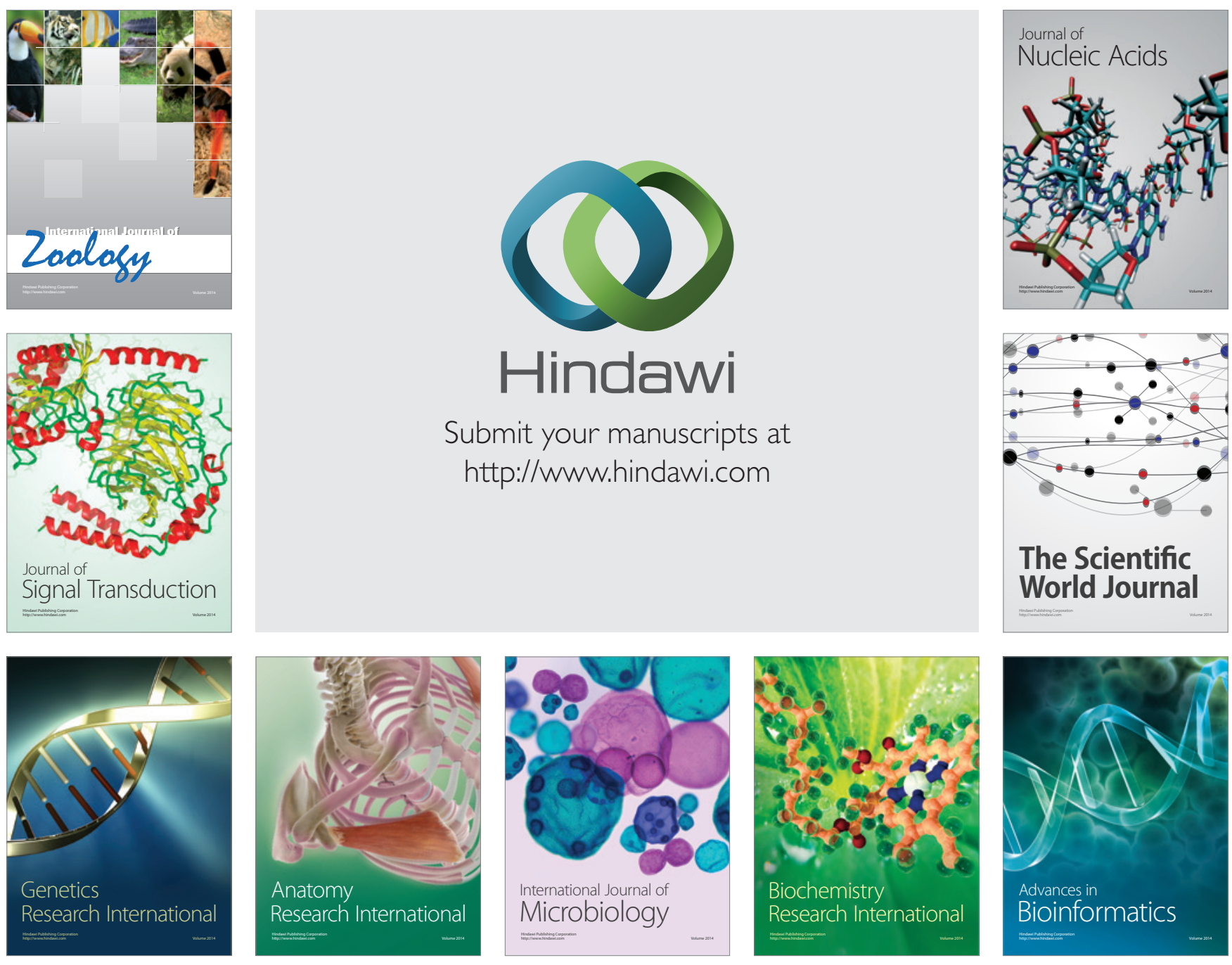

The Scientific World Journal
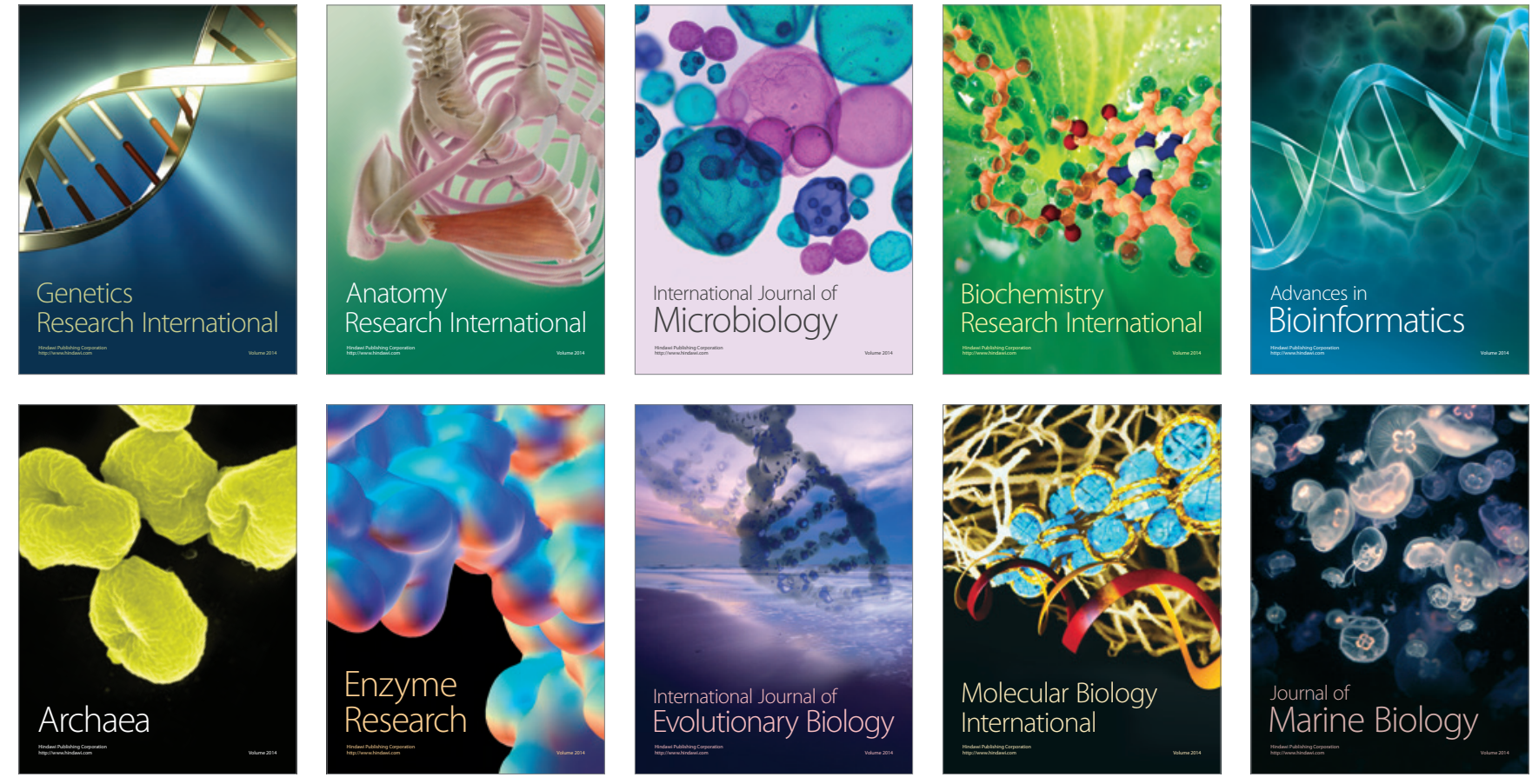